\title{
THE INCIDENCE OF SLEEP DISTURBANCES AMONG MEDICAL STUDENTS
}

\author{
Chernykh NYu, Skrebneva AV, Melikhova EP $\otimes$, Vasilieva MV
}

Burdenko Voronezh State Medical University

\begin{abstract}
Sleep disturbance is a common health problem that can influence the quality of life. There are several types of sleep disorders, such as obstructive sleep apnea, insomnia, narcolepsy, periodic limb movement disorder, and circadian dysregulation. Medical students are probably more prone to sleep disturbances due to their extreme academic stress. In this research, the incidence of sleep disturbance among medical students was examined, and the concomitant risk factors were determined. That was one-time research. A questioning was used to collect social, demographic and sleeping data. $6781^{\text {st }}, 2^{\text {nd }}$ and $3^{\text {rd }}$ year medical students were surveyed. $29 \%$ complained of at least one sleep disturbance. The most widely spread sleep disturbance observed among $51.8 \%$ medical students included insomnia (initial insomnia and sleep maintenance). $4^{\text {th }}$ year students and those who spend much time on smartphones were more prone to sleep disturbances. Sleep disturbances are common among medical students. They need to be discovered and paid attention to before the situation gets worse.
\end{abstract}

Keywords: students, sleep disorders, insomnia, health.

Author contributions: Literature analysis, research planning - Chernykh NY, Vasilieva MV, data collection and processing - Chernykh NY, Melikhova EP, Skrebneva AV, statistical processing - Skrebneva AV, editing - Melikhova EP.

Compliance with ethical standards: The participation was voluntary; all those surveyed signed an informed consent prior to study enrollment.

$\triangle$ Correspondence should be addressed: Ekaterina P. Melikhova

ul. Studencheskaya, 10, Voronezh, 394036, Russia; Katerina.2109@mail.ru

Received: 03.08.2021 Accepted: 22.08.2021 Published online: 30.09.2021

DOI: $10.24075 /$ rbh.2021.018

\section{РАСПРОСТРАНЕННОСТЬ НАРУШЕНИЙ СНА СРЕДИ СТУДЕНТОВ-МЕДИКОВ}

\author{
Н. Ю. Черных, А. В. Скребнева, Е. П. Мелихова $\bowtie$, М. В. Васильева
}

Воронежский государственный медицинский университет им. Н. Н. Бурденко, Воронеж, Россия

\begin{abstract}
Нарушения сна являются общей проблемой здоровья и могут повлиять на качество жизни. Существует несколько типов нарушений сна, таких как синдром обструктивного апноэ во сне, бессонница (инсомния), нарколепсия, периодическое двигательное расстройство конечностей, нарушения циркадного ритма. Студенты-медики, возможно, более склонны к развитию нарушений сна из-за их высокого академического напряжения. В настоящем исследовании оценивалась распространенность нарушений сна среди студентов-медиков, и определялись сопутствующие факторь риска. Обследование было единовременным. Для сбора социо-демографических данных и данных сна использовалось анкетирование. Опрошено 678 студентов-медиков трех лет обучения. 29\% жаловались, по крайней мере, на одно нарушение сна. Самые распространенные нарушения сна среди студентов были инсомнические - нарушения засыпания и поддержания сна - 51,8\%. Студентки, студенты четвертого года обучения и те, кто проводит значительное время за смартфонами, были более подвержены нарушениям сна. Нарушения сна распространены среди студентов-медиков. Необходимо обнаружить и обратить на них внимание прежде, чем ситуация ухудшится.
\end{abstract}

Ключевые слова: студенты, нарушения сна, инсомния, здоровье.

Вклад авторов: Анализ литературы, планирование исследования - Черных Н. Ю., Васильева М. В., сбор и обработка материала, написание текста Черных Н. Ю., Мелихова Е. П., Скребнева А. В., статистическая обработка - Скребнева А. В., редактирование - Мелихова Е. П.

Соблюдение этических стандартов: Участие было добровольным, все обследуемые подписали информированное согласие перед включением в исследование.

$\triangle$ Для корреспонденции: Мелихова Екатерина Петровна ул. Студенческая, 10, г. Воронеж, 394036, Россия; Katerina.2109@mail.ru

Поступила: 03.08.2021 Статья принята к печати: 22.08.2021 Опубликована онлайн: 30.09.2021

DOI: $10.24075 /$ rbh.2021.018

Sleep is a cornerstone of a human life. Our health is closely connected to our sleep. The sleep patterns are important to many physiological human functions such as learning capacity, consolidation of memory, neurocognitive functions and mental health $[1,2]$. Somnolence is one of the factors negatively affecting health. Sleep disruption can impair vigilance, attention and cognitive processes [3, 4, 5]. Research shows that sleep disturbances are connected to mental health and are early signs of anxiety and depression. Ignoring the sleep disturbances can result in impaired attention, underperformance, decreased overall health, and problems with social relations $[6,7,8,9]$. The prevalence of sleep loss varies between 22\% and 65\%.

Numerous chronic diseases such as hypertension, diabetes and coronary heart disease are also connected to deprivation of sleep $[10,11]$.
Medical students belong to the part of the population more prone to sleep deprivations as high academic load results in a lack of sleep [12]. Sleep disorders affect life quality, general health and learning progress. That's why the disorders need to be revealed until the problem is aggravated even more [13]. In medical students, deprivation of sleep influences cognitive functions. According to numerous studies, $70-76 \%$ of medical students have a bad sleep quality $[14,15,16]$. The research of sleep deprivation in this population is relevant due to the high influence on physical, mental and psychic health, and academic achievements.

\section{PURPOSE}

The research aims to reveal the prevalence of sleep disturbances among medical students by examining seven sleep disorders 
(obstructive apnea, insomnia, narcolepsy, restless leg syndrome (periodic limb movement disorder), circadian dysregulation, somnambulism and night fears).

\section{MATERIALS AND METHODS}

Students from the department of general medicine were involved into the research. From April 03 to June 27, 2020 $1,6682^{\text {nd }}$ to $4^{\text {th }}$ year students from the VSMU were enrolled. The Sleep-50 questionnaire was used. The $1^{\text {st }}, 5^{\text {th }}$ and $6^{\text {th }}$ year students and incomplete questionnaires were excluded. The total number of participants was 678 .

For investigational purposes, the sample size was determined with a known number of observations in the overall population according to A. M. Merkov's formula (1962):

$$
n=\frac{\left(p \times q \times t^{2} \times N\right)}{\left(N \times \Delta^{2}+p \times q \times t^{2}\right)}, \text { where }
$$

$\mathrm{n}$ — the minimum sample size;

$\mathrm{N}$ - the overall population;

$\mathrm{p}$ - the studied event probability (in this case, it is unknown, so we consider it equal to the maximum possible value, i.e. 50\%), the sign overall frequency;

$\mathrm{t}$ - the confidence factor $(\mathrm{t}=2$ at $\mathrm{p}=0,05)$;

$\triangle$ - the error margin (5\%);

$q$ - the optionality (100-p).

The values of $t$ and $\Delta$ are selected to observe the high confidence of poll results (in $95 \%$ of cases the maximum error was $5 \%)$.

The overall population $(\mathrm{N})$ of students was 1,668. Thus, the sample was (people):

$$
n=\frac{\left(50 \times 50 \times 2^{2} \times 1668\right)}{\left(1668 \times 5^{2}+50 \times 50 \times 2^{2}\right)}=323
$$

The study can be considered representative when it is participated by at least 323 people.

The interview consisted of two parts. The first part included social and demographic data such as age, gender, family status, body mass index (BMI). The academic year and average score were registered. The questionnaire included questions about chronic diseases, sleep disturbance family history, smoking status, coffee consumption, time spent on smartphones and/or TV. It was found out whether the student performed physical exercises within two hours before sleep and whether he/she slept in a very cold room. The second part embraced the Sleep-50 questionnaire [16].

The research uses the Sleep-50 questionnaire scale validated by Sportmaker and his point rating system. The questionnaire consisted of 50 questions (items) and 7 sections



Fig.1. Distribution of students by course years, $\%$ (subscales). Each subscale was used to estimate a particular sleep disturbance.

The results were calculated on a 4-point grading scale (1 - not at all; 2 - some; 3 - much; 4 - very much) [17]. 3 or 4 scores assigned to any item pointed at a symptom of a particular sleep disorder.

The analysis of the correlation between social and demographic data and sleep disturbances was performed. The MicrosoftExcel 2013 program was used to process the values. Parametric methods such as calculation of average group values (M), the average data error $(\mathrm{m})$ and use of the Student's t-test (t) were utilized to estimate the statistical significance of group values. Meanwhile, the possibility of a statistical error concerning the conclusion about the statistical value significance was less than $5 \%(p<0.05)$.

\section{RESULTS}

The participants had the following general characteristics. There were 268, 244 and $1662^{\text {nd }}, 3^{\text {rd }}$ and $4^{\text {th }}$ year students, respectively (fig. 1), with 388 women and 290 men (fig. 2).

Only $7 \%$ of those surveyed were married. $15.8 \%$ of them had chronic diseases. $17 \%$ of students smoked, $80 \%$ had strong coffee, $15 \%$ had sleep disturbances in family history, $8 \%$ exercised for two hours before bedtime and $7 \%$ slept in a very cold room.

The Sleep-50 questionnaire was used to diagnose the most frequent sleep disturbances. 29\% complained of at least one sleep disturbance. Initial insomnia and sleep maintenance were the most frequent disorders that amounted to $51.8 \%$ (fig. 3).

Combined sleep disturbances were determined. 3.2\% of those surveyed reported two combined sleep disturbances, whereas $2.1 \%$ of them had three combined sleep disorders.

The relation between sleep disturbances and several academic and social variables were examined. No significant differences were found between poor academic performance, body mass index and sleep disorders. No difference in the average scoring was found among students with and without sleeping disorders. However, significant differences were found in the time spent by the students on TV and/or smartphones and sleeping disorders $(p<0.05)$. The correlation ratio between two variable was 0.75 (according to the Chaddock scale).

A correlation between the categorical variable and sleep disturbances was discovered. There was an interaction between a gender and sleep disorder, as women had the problem more frequently than men.

Considering an insignificant sample, the analysis of the correlation between sleep disturbances and family status is not representative ( $7 \%$ of those surveyed).

Moreover, an increasing intensity of sleep disturbances was observed during the $2^{\text {nd }}-4^{\text {th }}$ years of studying at the University. The relation with other categorical values was insignificant.

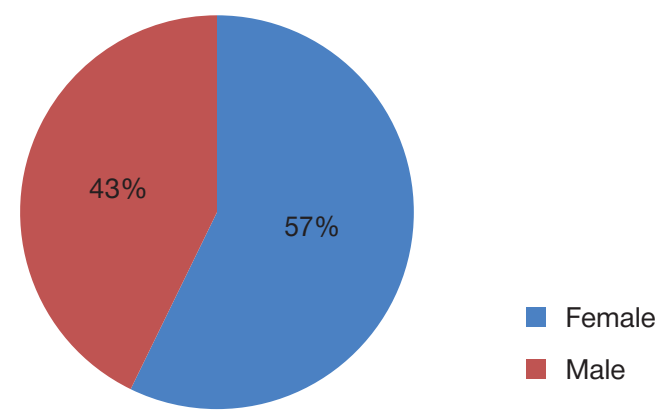

Fig. 2. Distribution of students by gender, $\%$ 


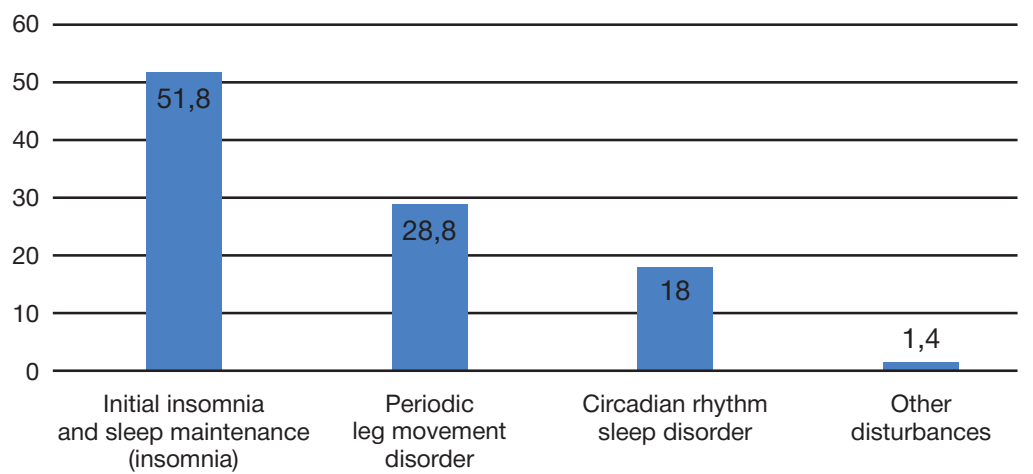

Fig. 3. Distribution of sleep disturbance types, $\%$

\section{DISCUSSION OF RESULTS}

A certain level of sleep disturbances, increased during the studying, was determined among medical students. According to other studies, the disturbances influence memory consolidation, learning ability, physiological functions and general health [18].

We observed the relation between time spent on TV and smartphones and sleep disturbances. The mean time spent on TV and smartphones by medical students suffering from sleep disturbances was 7 hours. On the other hand, those without sleeping disturbances spent about 5 hours on the same.

This was also seen during researches involving medical students. For instance, in Iran, the incidence of excessive use of mobile phones was $10.7 \%$, whereas the incidence of bad sleep quality was $61.7 \%$

A similar study in India has shown that over two thirds of medical students had poor sleep quality because they used mobile phones for a long time. Hossein and other researchers found out that surfing social media on smartphones negatively affected the academic achievements [19]. In any case, sleep disturbances developed due to excessive use of mobile phones can be an intermediate step towards possible poor academic achievement.

A connection between gender and sleep disturbances was another important outcome of this research. Women are psychologically more dependent on their environment as compared with men. They have a more pronounced need to inform someone of their bad sleep. A greater risk of sleep disturbance in female students can be associated with a menstrual cycle.

It is of note that the research was conducted during a continuous global COVID-19 crisis accompanied by accumulation of stress among students. Their participation in the academic life was significantly reduced. According to many authors, an increased level of anxiety and stress was determined in medical education [20, 21, 22, 23, 24, 25].

\section{CONCLUSION}

Sleeping disorders are common among medical students. The disorders produce an impact on their physical, mental and psychological health. The problems must be revealed and solved until the condition is aggravated. Sleeping disorders are more common in seniors. It means the number of disorders is constantly increased as learning goes on. Female students are at a higher risk. Medical students have to be well aware of the time spent on TV and mobile phones.

The consequences of the global COVID-19 crisis continued in 2020-2021 and intense use of mobile phones and social media are depicted on the sleeping model of medical students. The issues need further discussion.

\section{References}

1. Carley DW, Farabi SS. Physiology of sleep. Diabetes spectr. 2016; 29: 5-9. URL: https://doi.org/10.2337/diaspect.29.1.5 (дата обращения 11.02.21)

2. Baviskar M, Giri P, Phalke D. Study of sleep habits and sleep problems among medical students of Pravara Institute of Medical Sciences, Loni. Ann Med Health Sci Res. 2013; 3: 51-4. URL: https://doi.org/10.4103/2141-9248.109488 (дата обращения 11.02.21)

3. Curcio G, Ferrara M, De Gennaro L. Sleep loss, learning capacity and academic performance. Sleep Med Rev. 2006; 10: 32337. URL: https://doi.org/10.1016/j.smrv.2005.11.001 (дата обращения 19.02.21)

4. Fenn KM, \& Hambrick DZ. Individual differences in working memory capacity predict sleep-dependent memory consolidation. Journal of Experimental Psychology: General. 2012; 141(3), 404-410. https://doi.org/10.1037/a0025268 (дата обращения 19.02.21)

5. Jewett $M$, Dijk D-J, Kronauer R, Dinges D. Dose-response relationship between sleep duration and human psychomotor vigilance and subjective alertness. Sleep 1999; 22: 171-9. URL: https://doi.org/10.1093/sleep/22.2.171(дата обращения 11.02.21)

6. Yoo SS, Hu P, Gujar N. A deficit in the ability to form new human memories without sleep. Nature Neurosci. 2007; 10: 38592. URL: https://doi.org/10.1038/nn1851 (дата обращения 19.02.21)

7. Eller T, Aluoja A, Vasar V, Veldi M. Symptoms of anxiety and depression in Estonian medical students with sleep problems. Depression Anxiety. 2006; 23:250-6. URL: https://doi. org/10.1002/da.20166 (дата обращения 19.02.21)

8. Carney $\mathrm{C}$, Edingeret $\mathrm{J}$ al. Daily activities and sleep quality in college students. Chronobiollnt. 2006; 23: 623-37. URL: https:// doi.org/10.1080/07420520600650695 (дата обращения 19.02.21)

9. O'Brien EM, Mindell JA. Sleep and risk-taking behavior in adolescents. BehavSleepMed. 2005;3:113-33. URL: https://doi. org/10.1207/s15402010bsm0303_1(дата обращения 19.02.21)

10. Smaldone A, Honig J, Byrne M. Sleepless in America: Inadequate Sleep and Relationships to Health and Well-being of Our Nation's Children. Pediatrics. 2007; 119: S29-37. URL: https://doi. org/10.1542/peds.2006-2089F (дата обращения 19.02.21)

11. Veldi M, Aluoja A, Vasar V. Sleep quality and more common sleep-related problems in medical students. Sleep Med. 2005; 6: 
269-75. URL: https://doi.org/10.1016/j.sleep.2004.12.003(дата обращения 19.02.21)

12. Doane LD, Gress-Smith JL, Breitenstein RS. Multi-method assessments of sleep over the transition to college and the associations with depression and anxiety symptoms. J Youth Adolesc. 2015; 44: 389-404.

13. URL: https://doi.org/10.1007/s10964-014-0150-7 (дата обращения 19.02.21)

14. Wong JG, Patil NG, Beh SL. Cultivating psychological well-being in Hong Kong's future doctors. Med Teach. 2005; 27: 715-9. URL: https://doi.org/10.1080/01421590500237945 (дата обращения 19.02.21)

15. Azad M, Fraser $\mathrm{K}$ et al.. Sleep disturbances among medical students: a global perspective. J Clin Sleep Med. 2015; 11: 69-74. URL: https://doi.org/10.5664/jcsm.4370 (дата обращения 19.02.21)

16. Parkerson GR, Broadhead WE, Tse CK. The health status and life satisfaction of first-year medical students. Acad Med. 1990; 65: 586-8. URL: https://doi.org/10.1097/00001888-19900900000009 (дата обращения 19.02.21)

17. Spoormaker VI, Verbeek I, Jvan den Bout, Klip EC. Initial validation of the SLEEP-50 questionnaire. Behav Sleep Med 2005; 3: 227 46. URL: https://doi.org/10.1207/s15402010bsm0304_4 (дата обращения 19.02.21)

18. Lima PF, Medeiros AL, Araujo JF. Sleep-wake pattern of medical students: early versus late class starting time. Brazilian J Med Biol Res. 2002; 35: 1373-7. URL: https://doi.org/10.1590/S0100879X2002001100016 (дата обращения 19.02.21)

19. Abdulghani HM, Alrowais NA et al.Sleep disorder among medical students: relationship to their academic performance. Med Teach. 2012; 34: S37-41. URL: https://doi.org/10.3109/01421 59X.2012.656749 (дата обращения 19.02.21)

\section{Литература}

1. Carley DW, Farabi SS. Physiology of sleep. Diabetes spectr. 2016; 29: 5-9. URL: https://doi.org/10.2337/diaspect.29.1.5 (дата обращения 11.02.21)

2. Baviskar M, Giri P, Phalke D. Study of sleep habits and sleep problems among medical students of Pravara Institute of Medical Sciences, Loni. Ann Med Health Sci Res. 2013; 3: 51-4. URL: https://doi.org/10.4103/2141-9248.109488 (дата обращения 11.02.21)

3. Curcio G, Ferrara M, De Gennaro L. Sleep loss, learning capacity and academic performance. Sleep Med Rev. 2006; 10: 32337. URL: https://doi.org/10.1016/j.smrv.2005.11.001 (дата обращения 19.02.21)

4. Fenn $\mathrm{KM}$, \& Hambrick DZ. Individual differences in working memory capacity predict sleep-dependent memory consolidation. Journal of Experimental Psychology: General. 2012; 141(3), 404-410. https://doi.org/10.1037/a0025268 (дата обращения 19.02.21)

5. Jewett M, Dijk D-J, Kronauer R, Dinges D. Dose-response relationship between sleep duration and human psychomotor vigilance and subjective alertness. Sleep 1999; 22: 171-9. URL: https://doi.org/10.1093/sleep/22.2.171(дата обращения 11.02.21)

6. Yoo SS, Hu P, Gujar N. A deficit in the ability to form new human memories without sleep. Nature Neurosci. 2007; 10: 38592. URL: https://doi.org/10.1038/nn1851 (дата обращения 19.02.21)

7. Eller T, Aluoja A, Vasar V, Veldi M. Symptoms of anxiety and depression in Estonian medical students with sleep problems. Depression Anxiety. 2006; 23:250-6. URL: https://doi. org/10.1002/da.20166 (дата обращения 19.02.21)

8. Carney $\mathrm{C}$, Edingeret $\mathrm{J}$ al. Daily activities and sleep quality in college students. Chronobiollnt. 2006; 23: 623-37. URL: https:// doi.org/10.1080/07420520600650695 (дата обращения 19.02.21)

9. O'Brien EM, Mindell JA. Sleep and risk-taking behavior in adolescents. BehavSleepMed. 2005;3:113-33.-URL: https://doi. org/10.1207/s15402010bsm0303_1(дата обращения 19.02.21)
20. Taylor $\mathrm{D}, \mathrm{Bramoweth} \mathrm{AD}$ et al. Epidemiology of insomnia in college students: relationship with mental health, quality of life, and substance use difficultie. Behavior Ther. 2013; 44: 339-48. URL: https://doi.org/10.1016/j.beth.2012.12.001 (дата обращения 19.02.21)

21. Hossain S, Nurunnabi M, Hussain K, Saha S. Effects of variety seeking intention by mobile phone usage on university students' academic performance. Cogent Educ. 2019; 6. URL: https:// doi.org/10.1080/2331186X.2019.1574692 (дата обращения 01.03.21)

22. Alsaggaf M, Wali S, Merdad R, Merdad L. Sleep quantity, quality, and insomnia symptoms of medical students during clinical years: Relationship with stress and academic performance. Saudi Med J. 2016; 37: 173-82. URL: https://doi.org/10.15537/ smj.2016.2.14288 (дата обращения 01.03.21)

23. Gaultney J. The prevalence of sleep disorders in college students: impact on academic performance. J American Coll Health. 2010; 59: 91-7. URL: https://doi.org/10.1080/07448481.2010.483708 (дата обращения 01.03.21)

24. Sundarasen $S$, Chinna $K$ et al. Psychological impact of COVID-19 and lockdown among university students in Malaysia: implications and policy recommendations. Int J Environ Res Public Health. 2020; 17: 6206. URL: https://doi.org/10.3390/ ijerph17176206(дата обращения01.03.21)

25. Ferrel MN, Ryan JJ. The Impact of COVID-19 on medical education. Cureus. 2020; 12: e7492. URL: https://doi. org/10.7759/cureus.7492(дата обращения 01.03.21)

26. Torun F, Torun S. The psychological impact of the COVID-19 pandemic on medical students in Turkey. Pakistan J Med Sci. 2020; 36. URL: https://doi.org/10.12669/pjms.36.6.2985 (дата обращения 01.03.21)

10. Smaldone A, Honig J, Byrne M. Sleepless in America: Inadequate Sleep and Relationships to Health and Well-being of Our Nation's Children. Pediatrics. 2007; 119: S29-37. URL: https://doi.org/10.1542/peds.2006-2089F (дата обращения 19.02.21)

11. Veldi M, Aluoja A, Vasar V. Sleep quality and more common sleep-related problems in medical students. Sleep Med. 2005; 6: 269-75. URL: https://doi.org/10.1016/j.sleep.2004.12.003(дата обращения 19.02.21)

12. Doane LD, Gress-Smith JL, Breitenstein RS. Multi-method assessments of sleep over the transition to college and the associations with depression and anxiety symptoms. J Youth Adolesc. 2015; 44: 389-404.

13. URL: https://doi.org/10.1007/s10964-014-0150-7 (дата обращения 19.02.21)

14. Wong JG, Patil NG, Beh SL. Cultivating psychological well-being in Hong Kong's future doctors. Med Teach. 2005; 27: 715-9. URL: https://doi.org/10.1080/01421590500237945 (дата обращения 19.02.21)

15. Azad $\mathrm{M}$, Fraser $\mathrm{K}$ et al.. Sleep disturbances among medical students: a global perspective. J Clin Sleep Med. 2015;11: 6974. URL: https://doi.org/10.5664/jcsm.4370 (дата обращения 19.02.21)

16. Parkerson GR, Broadhead WE, Tse CK. The health status and life satisfaction of first-year medical students. Acad Med. 1990; 65: 586-8. URL: https://doi.org/10.1097/00001888-19900900000009 (дата обращения 19.02.21)

17. Spoormaker VI, Verbeek I, Jvan den Bout, Klip EC. Initial validation of the SLEEP-50 questionnaire. Behav Sleep Med 2005; 3: 22746. URL: https://doi.org/10.1207/s15402010bsm0304_4 (дата обращения 19.02.21)

18. Lima PF, Medeiros AL, Araujo JF. Sleep-wake pattern of medical students: early versus late class starting time. Brazilian J Med Biol Res. 2002; 35: 1373-7. URL: https://doi.org/10.1590/S0100879X2002001100016 (дата обращения 19.02.21)

19. Abdulghani HM, Alrowais NA et al. Sleep disorder among medical students: relationship to their academic performance. Med 
Teach. 2012; 34: S37-41. URL: https://doi.org/10.3109/01421 59X.2012.656749 (дата обращения 19.02.21)

20. Taylor $D$, Bramoweth $A D$ et al. Epidemiology of insomnia in college students: relationship with mental health, quality of life, and substance use difficultie. Behavior Ther. 2013; 44: 339-48. URL: https://doi. org/10.1016/j.beth.2012.12.001 (дата обращения 19.02.21)

21. Hossain S, Nurunnabi M, Hussain K, Saha S. Effects of variety seeking intention by mobile phone usage on university students academic performance. Cogent Educ. 2019; 6. URL: https:// doi.org/10.1080/2331186X.2019.1574692 (дата обращения 01.03.21)

22. Alsaggaf M, Wali S, Merdad R, Merdad L. Sleep quantity, quality, and insomnia symptoms of medical students during clinical years: Relationship with stress and academic performance. Saudi Med J. 2016; 37: 173-82. URL: https://doi.org/10.15537/ smj.2016.2.14288 (дата обращения 01.03.21)
23. Gaultney J. The prevalence of sleep disorders in college students: impact on academic performance. J American Coll Health. 2010; 59: 91-7. URL: https://doi.org/10.1080/07448481.2010.483708 (дата обращения 01.03.21)

24. Sundarasen $S$, Chinna $K$ et al. Psychological impact of COVID-19 and lockdown among university students in Malaysia: implications and policy recommendations. Int J Environ Res Public Health. 2020; 17: 6206. URL: https://doi.org/10.3390/ ijerph17176206(дата обращения01.03.21)

25. Ferrel MN, Ryan JJ. The Impact of COVID-19 on medical education. Cureus. 2020; 12: e7492. URL: https://doi. org/10.7759/cureus.7492(дата обращения 01.03.21)

26. Torun F, Torun S. The psychological impact of the COVID-19 pandemic on medical students in Turkey. Pakistan J Med Sci. 2020; 36. URL: https://doi.org/10.12669/pjms.36.6.2985 (дата обращения 01.03.21) 